\title{
Pendampingan Gerakan Pendidikan Lingkungan di 12 Lembaga Pendidikan Dasar (SD \& MI) di Area Pendukung Kawasan Konservasi Kebun Raya Purwodadi Kabupaten Pasuruan
}

\author{
Zainul Ahwan', Mochamad Hasyim ${ }^{1}$, Buhajar $^{2}$, Rudi $^{3}$ \\ ${ }^{1}$ Universitas Yudharta Pasuruan, ${ }^{2}$ Randuwana Learning Center, ${ }^{3}$ PT.TBINA \\ Purwosari \\ zezen@yudharta.ac.id, hasyim@yudharta.ac.id
}

\begin{abstract}
Abstrak:
Program pendampingan gerakan pendidikan lingkungan di 12 lembaga pendidikan dasar (SD \& MI) di area pendukung kawasan konservasi Kebun Raya Purwodadi Kabupaten Pasuruan Desa Capang, Desa Kertosari dan Desa Tejowangi Kabupaten Pasuruan ini telah dilaksanakan selama 5 bulan mulai bulan Januari - Mei 2018. Program ini telah menghasilkan komunitas rintisan pendidikan adiwiyata di 3 desa yaitu desa Kertosari, Capang dan Tejowangi. Melalui program ini, telah mampu meningkatkan pengetahuan dan skill pada guru dan siswa di 12 lembaga pendidikan dasar mitra program dalam melakukan pendidikan penanaman karakter kepedulian lingkungan hidup pada siswa, selain itu, mitra program juga telah memiliki pengetahuan dan skill dalam pengelolaan lingkungan dikawasan sekolah melaui bank sampah sekolah dan penanaman dan pemanfaatan tanaman TOGA di masing-masing sekolah.
\end{abstract}

Kata Kunci: pendidikan lingkungan, pendidikan dasar, kawasan konservasi

\begin{abstract}
:
The environmental education movement assistance program in 12 elementary education institutions (SD \& MI) in the support area of the Purwodadi botanical garden conservation of Pasuruan Regency at Capang Village, Kertosari Village and Tejowangi Village Pasuruan Regency has been held for 5 months starting in January - May 2018. This program has produced a pilot community of adiwiyata education in 3 villages namely the villages of Kertosari, Capang and Tejowangi. Through this program, it has been able to improve the knowledge and skills of teachers and students in 12 basic educational institutions program partners in conducting education to instill environmental care characters in students, in addition, the program partners also have knowledge and skills in environmental management in the school area through school waste banks and planting and utilization of TOGA plants in each school.
\end{abstract}

Keyword: environmental education, basic education, conservation area 
178 | Pendampingan Gerakan Pendidikan Lingkungan di 12 Lembaga Pendidikan..

\section{Pendahuluan}

Persoalan alam dewasa ini menjadi pembicaraan hangat diberbagai belahan dunia. Isu global warming, climate change menjadi fokus kebijakan diberbagai negara. Berbagai anggapan juga muncul "Alam sudah tidak lagi bersabat dengan manusia", "alam menebar teror pada manusia" dan seterusnya. Term sedemikian muncul karena pada faktanya manusia lagi mengalami ketakutan dan traumatis dari adanya berbagai tragedi bencana alam yang akhir-akhir ini melanda berbagai kawasan baik di Indonesia dan luar negeri. Banjir, tanah longsor, kekeringan, gempa bumi, angin topan, badai katrina dll kerap terjadi diberbagai daerah. Dalam Agenda Rencana Aksi Nasional dalam Menghadapi Perubahan Iklim yang digagas oleh Kementerian Negara Lingkungan Hidup tahun 2007. Diungkapkan bahwa akibat bencana iklim diperkirakan tahun 2050, apabila pemanasan global terus terjadi dan tidak ada upaya-upaya adaptasi yang terencana yang dilakukan dari sekarang, maka diperkirakan akan mengakibatkan jumlah kematian bisa mencapai 100 Ribu Orang per-Tahun

Relevan dengan persolan lingkungan, di Kabupaten Pasuruan saja misalnya, bencana banjir menjadi bencana rutinan setiap tahun dimusim penghujan datang. Kejadian banjir di Kabupaten Pasuruan sering terjadi pada di Kecamatan Gempol, Kecamatan Beji, Kecamatan Rembang, Kecamatan Bangil, Kecamatan Kraton, Kecamatan Grati, Kecamatan Pohjentrek, Kecamatan Gondangwetan, Kecamatan Rejoso, Kecamatan Winongan, karena merupakan daerah hilir yang dipengaruhi adanya daerah aliran sungai.(RPJMD Kabupaten Pasuruan Tahun 2018-2023, 2019) 


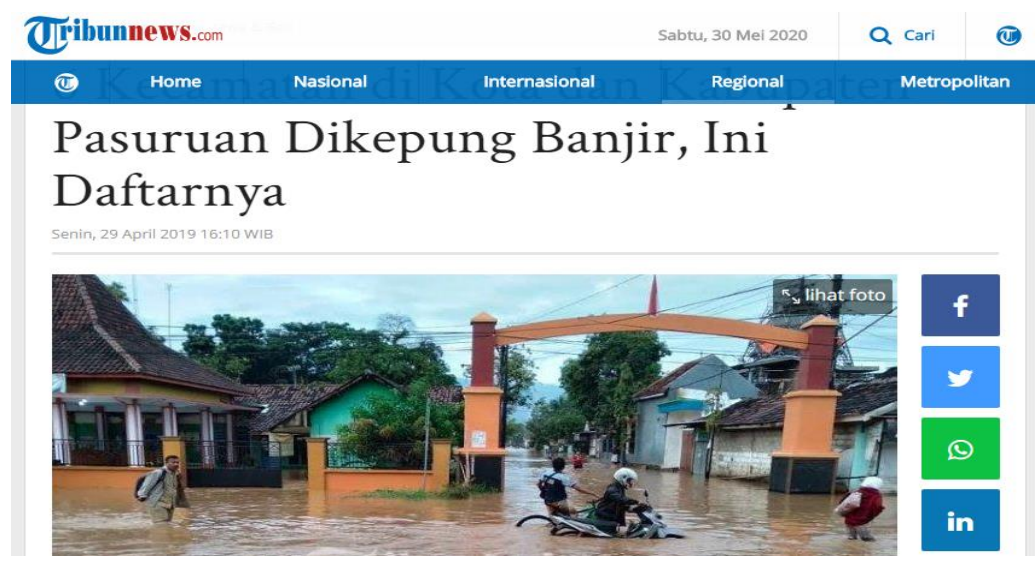

Gambar No.1 Berita Banjir di Kab. Pasuruan tahun 2019

Menurut Kepala Badan Penanggulangan Bencana Daerah (BPBD) Kabupaten Pasuruan, Bakti Jati Permana, yang dimuat dalam detiknews.com, Sabtu (12/11/2016) "Penyebab banjir Pasuruan sangat kompleks. Pertama penyempitan dan pendangkalan sungai, kemudian berkurangnya hutan di hulu sehingga air langsung turun saat hujan lebat, dan kondisi pasang surut air laut, buruknya drainase di sejumlah lokasi dan kebiasaan buang sampah sembarangan.(Arifin, 2016) Dalam hal persoalan sampah, Kabupaten Pasuruan adalah salah satu kota di Jawa Timur yang memiliki potensi sekaligus permasalahan terkait dengan tata kelola sampah yang cukup serius. Timbulan sampah di Kabupaten pasuruan dalam 1 hari mencapai sebesar 4.700 Meter Kubik sehingga menjadikan timbunan sampah di TPA Keneb Beji menjadi over loaded kapasitas.(Imron Rosadi, Faris, Zainul Ahwan, 2019)

Memang perlu disadari bahwa persoalan alam atau lingkungan hidup menjadi bagian persoalan kehidupan masyarakat yang cukup serius untuk segera disikapi secara arif dengan melibatkan banyak pihak baik pemerintah, masyarakat bahkan lembaga pendidikan mempunyai peran yang signifikan dalam membentuk karakter generasi yang mempunyai karakter cinta lingkungan. Untuka itu, Perlu adanya gerakan sosial nyata yang dilakukan oleh elemen masyarakat untuk mengurai persoalan alam dan lingkungan sesuai dengan peran masing-masing. 
180 | Pendampingan Gerakan Pendidikan Lingkungan di 12 Lembaga Pendidikan..

Sekecil apapun sebuah usaha pengelolaan lingkungan hidup menjadi sangat berati bagi kelangsungan kehidupan manusia dan makhluk lain disekitarnya. Selain itu, kepedulian terhadap lingkungan haruslah mulai ditanamkan sejak dini pada anak didik (siswa) dibangku sekolah dasar. Usia anak-anak merupakan satu fase usia keemasan (the golden ages). Usia ini merupakan usia yang mengalami perkembangan intelegensi yang paling optimal serta mengalami proses perkembangan intelegensi yang paling tinggi. Oleh karena itu usia keemasan adalah modal yang tak ternilai harganya untuk membina anak-anak bangsa. Penguatan nilai-nilai dan karakter positif cinta terhadap kelestarian lingkungan hidup menjadi aset masyarakat yang kelak akan menjelma menjadikan pribadipribadi generasi penerus bangsa yang punya kepedualian tinggi terhadap kelestarian lingkungan alam didaerahnya

\section{Tujuan}

1. Tujuan jangka panjang [Goal]:

Terwujudnya gerakan pendidikan lingkungan pada siswa SD di Desa Capang, Desa Kertosari dan Desa Tejowangi yang memiliki kesadaran tinggi pada pengelolaan lingkungan hidup di daerah sasaran program.

2. Tujuan jangka pendek:

1. Penanaman pengetahuan dan character building peduli lingkungan

2. Menumbuhkan rasa cinta lingkungan pada guru, siswa dan wali siswa

3. Memulai membudayakan gerakan lingkungan sehat melalui pusat pembelajaran inovatif berbasis lingkungan hidup pada siswa di 12 (dua belas) sekolah dasar (SD/MI) di Desa Capang, Desa Kertosari dan Desa Tejowangi

\section{Metode}

Program pengabdian kepada masyarakat (PKM) yang dilakukan pada target group pragram yaitu Sekolah Dasar (SD) atau Madrasah Islamiyah (MI) di 12 (dua belas) sekolah (SD/MI) di Area Pendukung Kawasan Konservasi Kebun Raya 
Purwodadi Kabupaten Pasuruan meliputi Desa Capang, Desa Kertosari dan Desa Tejowangi. Metode kegiatan ini menggunakan pendekatan pengorganisasian masyarakat Community Organizer (CO). Pengorganisasian masyarakat disini dimengerti sebagai suatu proses pembangunan kekuatan yang melibatkan berbagai pihak dalam menggali persoalan yang terjadi di masyarakat sasaran program dengan potensi-potensi yang ada dan melakukan intervensi agar terjadi perubahan ke arah yang lebih baik. Ada tiga hal yang terkait dalam pengertian pengorganisasian masyarakat ini, yakni (1) ada persoalan dan potensi untuk penyelesaian masalah, (2) intervensi ke arah perubahan, dan (3) pihak yang terkait dalam intervensi masyarakat.(Ahwan, Hasyim, \& Sunarno, 2019) Selain itu dalam program ini tim PKM jiga menggunakan startegi pendekatan program yaitu: (1) Pendidikan penyadaran (raising awareness). Strategi ini dilakukan untuk memberi kesadaran pada penerima manfaat langsung maupun tidak langsung mengenali situasi sosial khususnya pada persoalan pengelolaan lingkungan hidup. Pendidikan penyadaran berarti pula membuka akses informasi yang menjadi syarat bagi perubahan pola pikir dan perilaku. Dalam persoalan ini peran penting lembaga pendidikan diuntut untuk memiliki peran dalam membentuk karakter anak didiknya (siswa) yang mempunyai kepedulian dan tanggung jawab serta mencintai lingkungan hidup di daerahnya menjadi sangat setrategis untuk dilakukan. Lembaga pendidikan sebagai institusi yang berperan dalam melakukan investasi SDM masa depan bangsa dan negara. (2). Pengorganisasian sekolah. Setrategi ini sebagai upaya nyata membangun keterlibatan langsung penerima manfaat (benefitseries) khususnya direct benefitseries dalam implementasi program yang sesuai dengan target capaian yang diinginkan. (3) Memberikan layanan pada penerima manfaat. Strategi ini mempunyai maksud memberikan suport dan apresiasi penuh kepada penerima manfaat program baik berupa capacity building, pendampingan dan lain-lain yang berorientasi pada kesuksesan program yang dijalankan. (4). Keterlibatan (involvment) dan team work. Strategi ini disiapkan untuk membangun kondisi yang kondusif selama proses implementasi program. 
182 | Pendampingan Gerakan Pendidikan Lingkungan di 12 Lembaga Pendidikan..

Strategi ini mensyaratkan adanya keterlibatan mitra program secara penuh dalam implementasi program, membangun kesepakatan-kesepakatan dan kebijakan yang telah dibentuk diantara tim program dengan mitra program. Selain itu, dalam mewujudkan kondisi yang kondusif ini maka perlu dibangun jaringan kerja dengan pemangku kepentingan yang ada.

\section{Langkah-Langkah program sebagaimana berikut:}

1. Workshop inisiasi program

Workshop ini diorientasikan untuk memberikan gambaran secara komprehensip kepada target group tentang rencana program yang akan dijalankan bersamasama dengan mitra program yang meliputi peranan dan keterlibatan, periode waktu program, target group dan hasil yang ingin dicapai. Selain itu dalam workshop ini juga diorintasikan untuk mendapatkan feedback dan masukanmasukan konstruktif guna keberhasilan program yang akan dilaksanakan.

2. Pembuatan taman TOGA di sekolah

Kegiatan ini berupa pembuatan taman Toga di 12 lembaga pendidikan dasar mitra program. Pembuatan taman Toga ini sebagai media edukasi lingkungan pada siswa tentang jenis tanaman, nama latin serta pemanfaatannya untuk kesehatan.

3. Training Budidaya dan pemanfaatan TOGA di sekolah

Kegiatan ini bertujuan untuk memberikan pengetahuan dan skill kepada tim guru di sekolah mitra program tentang pengelolaan tanaman obat keluarga mulai dari proses penanaman, perawatan dan pemanfaatan pasca panen yang nantinya akan dijadikan sebagai bahan pembelajaran pada siswa.

4. Pembuatan Bank Sampah dan training bank sampah di sekolah Training pengelolaan sampah di sekolah

Kegiatan ini membekali pengetahuan dan skill pada guru terkait pengelolaan sampah yang ada disekolah serta melakukan penanganan sampah melalui konsep 3 R (Reuse, Reduce, Recycle) 
Matrik Program

\begin{tabular}{|c|c|c|c|c|}
\hline No & Kegiatan & Aktivitas & Partisipan & Lokasi \\
\hline 1 & $\begin{array}{l}\text { Need } \\
\text { Assesment }\end{array}$ & 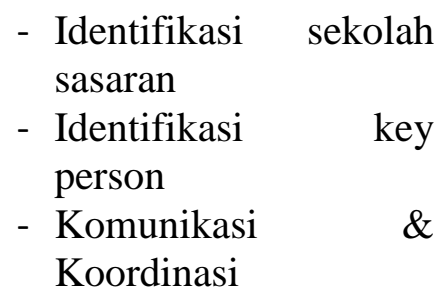 & $\begin{array}{l}\text { Tim } \\
\text { Program \& } \\
\text { PT. TBINA }\end{array}$ & Sekolah \\
\hline 2 & $\begin{array}{l}\text { Workshop } \\
\text { Inisiasi Program }\end{array}$ & $\begin{array}{l}\text { - Identifikasi peserta } \\
\text { - Menentukan tempat } \\
\text { - Pelaksanaan } \\
\text { sosialisasi } \\
\text { - Evaluasi internal }\end{array}$ & $\begin{array}{l}12 \text { orang } \\
\text { (Kepala } \\
\text { Sekola) }\end{array}$ & $\begin{array}{l}\text { Randuwa } \\
\text { na } \\
\text { Learning } \\
\text { Center }\end{array}$ \\
\hline 3 & $\begin{array}{l}\text { Pembuatan } \\
\text { taman TOGA di } \\
\text { sekolah }\end{array}$ & $\begin{array}{l}\text { - Penyiapan tanaman } \\
\text { dan alat kebutuhan } \\
\text { taman TOGA } \\
\text { - Distribusi tanaman } \\
\text { TOGA ke sekolah }\end{array}$ & $\begin{array}{l}\text { Tim } \\
\text { Program }\end{array}$ & $\begin{array}{l}\text { Randuwa } \\
\text { na } \\
\text { Learning } \\
\text { Center }\end{array}$ \\
\hline 4 & $\begin{array}{l}\text { Training } \\
\text { Budidaya dan } \\
\text { pemanfaatan } \\
\text { TOGA }\end{array}$ & $\begin{array}{l}\text { - Identifikasi peserta, } \\
\text { narasumber dan } \\
\text { fasilitator } \\
\text { - Persiapan materi dan } \\
\text { instrumen pelatihan } \\
\text { - Penyiapan tanaman } \\
\text { TOGA } \\
\text { - Pelaksanaan pelatihan } \\
\text { - Evaluasi internal tim }\end{array}$ & $\begin{array}{l}24 \text { Guru } \\
\text { dari } 12 \\
\text { lembaga }\end{array}$ & $\begin{array}{l}\text { Randuwa } \\
\text { na } \\
\text { Learning } \\
\text { Center }\end{array}$ \\
\hline 5 & \begin{tabular}{|l|} 
Pembuatan \\
Bank Sampah \\
dan training \\
bank sampah di \\
sekolah
\end{tabular} & $\begin{array}{l}\text { - Identifikasi peserta, } \\
\text { narasumber dan } \\
\text { fasilitator } \\
\text { - Persiapan materi dan } \\
\text { instrumen pelatihan } \\
\text { - Pelaksanaan pelatihan }\end{array}$ & $\begin{array}{l}24 \text { Guru } \\
\text { dari } 12 \\
\text { lembaga }\end{array}$ & $\begin{array}{l}\text { Randuwa } \\
\text { na } \\
\text { Learning } \\
\text { Center }\end{array}$ \\
\hline
\end{tabular}


184 | Pendampingan Gerakan Pendidikan Lingkungan di 12 Lembaga Pendidikan..

\section{Hasil dan Diskusi}

\section{Penyajian Data PKM}

\subsection{Profil Mitra Sasaran Program}

Program pendampingan Gerakan Pendidikan Lingkungan di 12 Lembaga Pendidikan Dasar (SD \& MI) di Desa Capang, Desa Kertosari dan Desa Tejowangi ini melibatkan sekolah-sekolah berikut: di Desa Kertosari sejumlah 4 lembaga, yaitu SDN Kertosari 1, SDN Kertosari 2, MI Hidayatul Mubtadiin, MI Miftahul Huda, di Desa Capang terdiri dari 3 lembaga, yaitu SDN Capang II, MI Miftahul Falah dan di Desa Tejowangi terdiri dari 5 lembaga, yaitu SDN Tejowangi 1, SDN Tejowangi 2, SDN Tejowangi 3, MI Miftahul Huda, MI Miftahul Ulum. Pemilihan mitra program dalam program pengabdian kepada masyarakat ini didasarkan pada lokasi sekolah merupakan daerah kawasan konservasi alam Kebun Raya Purwodadi Kab. Pasuruan serta penyangga gunung Mbaung yang menjadi fokus dan konsentrasi pengembangan kawasan hijau lemabaga Randuwana learning Center. Dalam pelaksanaannya program pengabdian kepada masyarakat ini dilaksanakan dengan melibatkan multipihak yaitu PT, TBINA Plant Purwosari Pasuruan, Randuwana Learning Center serta Universiats Yudharta Pasuruan.

\subsection{Workshop Inisiasi Program}

Kegiatan ini dilakasanakan pada Rabu, 14 Februari 2018 di Balai Diklat Randuwana Learning Center dihadiri 24 Guru perwakilan dari 12 lemabaga pendidikan dasar, perwakilan UPTD Pendidikan Kec. Purwosari serta Perwakilan PT. TBINA. Kegiatan ini dipandu olef fasilitator utama Zainul Ahwan, M.I.Kom serta Arif H. Ayik dari Randuwana Learning Center. Kegiatan ini diorientasikan untuk memberikan gambaran tentang proyeksi program yang akan dilakukan, waktu lama pelaksanaan program serta bagiamana membangun komitmen dan keterlibatan semua pihak dalam mendorong kesuksesan program. Selain itu, melalui workshop inisiasi program ini, diharapkan tercipta persepsi dan pemahaman bersama tentang arti pentingnya pendidikan lingkungan hidup yang perlu ditanamkan dan dilakukan sejak dini dengan melibatkan anak didik di tingkat 
sekolah dasar. Dalam kegiatan Workshop ini telah menghasilkan kesepakatan bersama 12 lembaga pendidikan dasar berkomitmen untuk terlibat dalam program pendidikan karakter berwasawan lingkungan hidup pada siswa sekolah dasar sebagai upaya inisiasi sekolah adiwiyata dikawasan Kebun Raya Purwodadi Kabupaten Pasuruan.
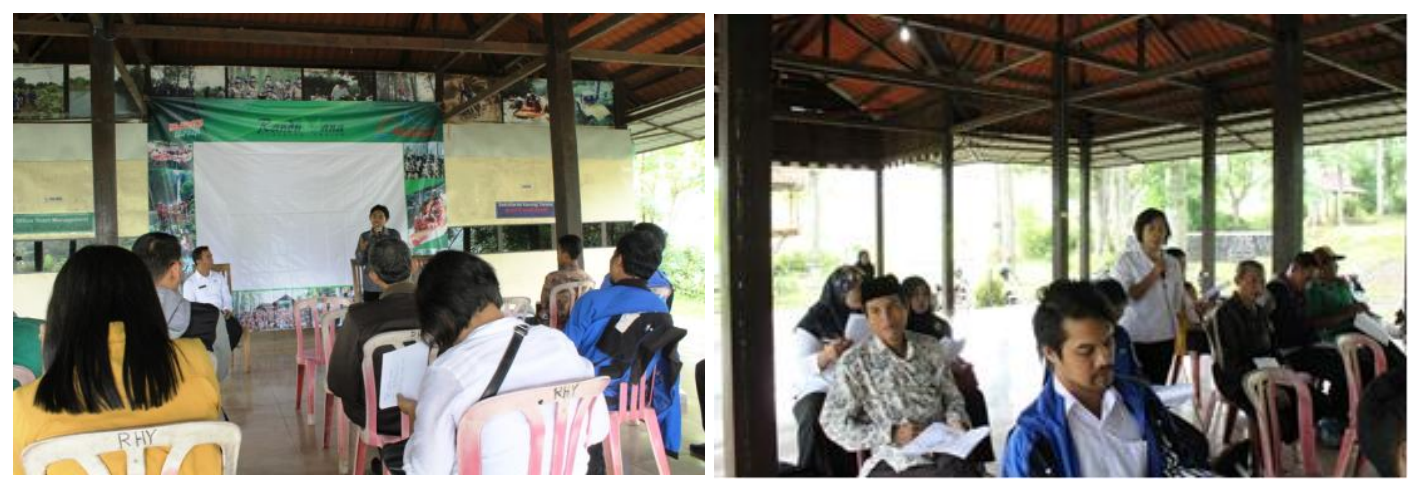

Gambar No.2 Workshop Inisiasi Program

\subsection{Pembuatan taman TOGA di sekolah}

Kegiatan ini dilaksanakan di 12 sekolah sasaran program dengan memberikan fasilitas kebutuhan Tanaman Obat Keluarga (Toga) yang dilaksanakan selama bulan Januari-Februari 2018. Kegiatan ini dimulai dengan pemberian bibit tanaman TOGA kepada masing-masing sekolah yang nantinya akan dijadikan sebagai taman TOGA dengan dilengkapi literasi nama tanaman dari sisi nama indonesia dan nama latinnya serta kandungan khasiat yang dimiliki oleh masingmasing tanaman. Melalui taman TOGA ini, siswa diedukasi tentang potensi tanaman TOGA serta khazanah pengobatan tradisonal yang telah ada di negeri ini. Pembuatan taman TOGA ini juga dimaksudkan sebagai bagaian dari gerakan pendidikan lingkungan sejak dini pada siswa sekolah dasar. Melalui kegiatan ini telah tercipta 12 taman TOGA di sekolah sasaran program. 

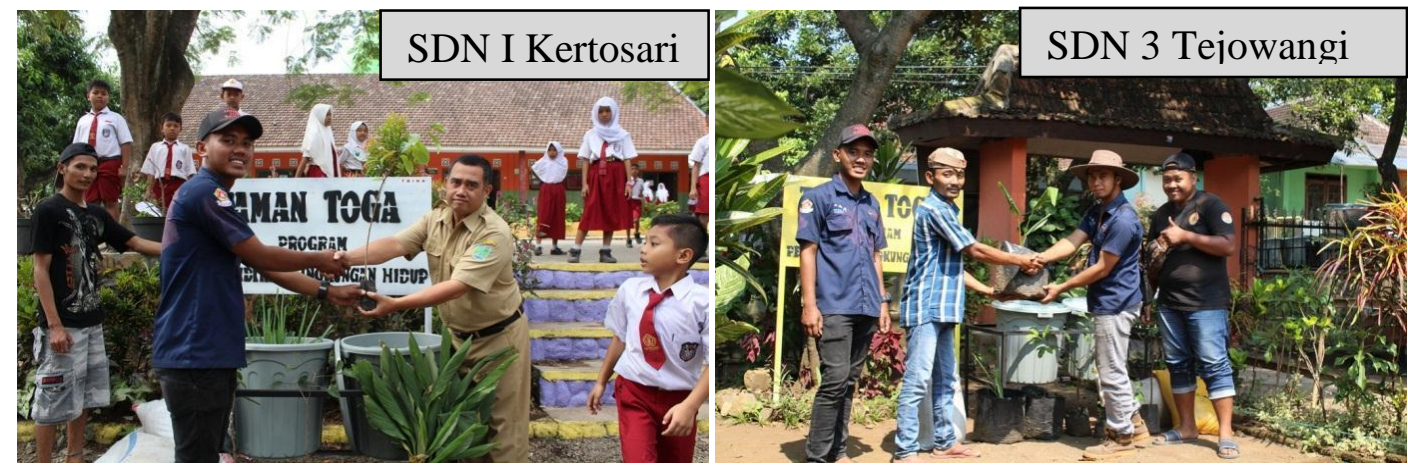

Gambar No.3 Penyerahan dan Pembuatan Taman TOGA

\subsection{Training Budidaya dan Pemanfaatan TOGA}

Kegiatan ini dilaksanakan pada Rabu, 16 Maret 2018 bertempat di Balai Diklat Randuwana learning center - Desa Wisata Kertosari Kabupaten Pasuruan dengan melibatkan 24 Guru dari 12 sekolah. Kegiatan ini difasilitatori oleh Zainul Ahwan, M.I.Kom dengan narasumber dari Lembaga Ilmu Pengetahuan Indonesia (LIPI) Kebun Raya Purwodadi yaitu Bapak Pa'i, SP. Dalam pelaksanaannya pelatihan ini dibagi dalam tiga sesi utama yaitu : Pertama Sesi materi, peserta dibekali pengetahuan tentang tanaman obat keluarga (TOGA) mulai dari nama, jenis dan kegunaannya. Kedua Sesi Obeservasi, Narasumber dan fasilitator mengajak peserta pelatihan untuk berkeliling di samping Balai Diklat Randuwana untuk melihat jenis-jenis Toga. Sesekali disampaikan oleh narasumber khasiat dan juga teknik terbaik dalam membudidayakannya. Ketiga Sesi Praktek, dalam sesi ini peserta diajak melakukan praktek secara langsung teknik menanam dengan media yang telah disediakan mulai dari bibit, komposisi media tanam berupa kompos, tanah dan sekem, polybag, dan lain-lain. 

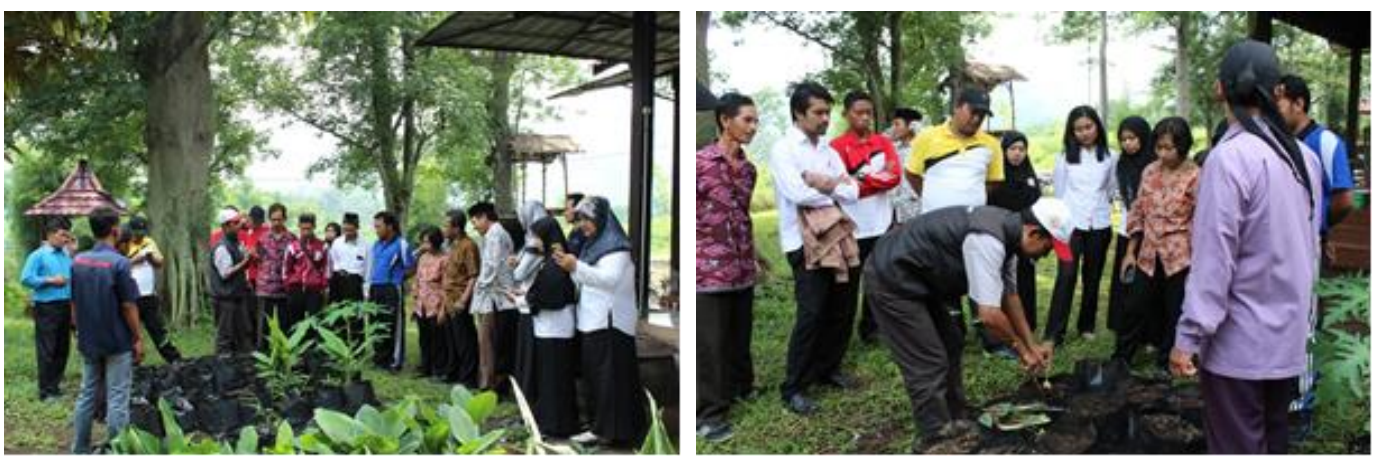

Gambar No.4 Pelatihan pengelolaan dan pemanfaatan TOGA

\subsection{Training Bank Sampah di sekolah}

Kegiatan ini dilaksanakan pada hari Sabtu, 28 Maret 2018 bertempat di Balai Diklat Randuwana Learning Cneter Desa Wisata Kertosari Kabupaten Pasuruan.kegiatan tersebut dihadiri 24 peserta perwakilan guru dari 12 sekolah mitra program. Training bank sampah di sekolah ini difasilitatori oleh Zainul Ahwan, M.I.Kom. kegiatan ini telah memberikan perubahan pengetahuna dan skill pada guru tentang pentingnya pengelolaan sampah disekolah yang melibatkan siswa, guru serta wali siswa secara terprogram dalam bentuk organisasi bank sampah sekolah. Selain itu, para guru juga memahami bagaimana mensinergikan mata pelajaran dengan pendidikan lingkungan di sekolah masing-masing. Melalui ini siswa akan terlibat aktif dan memiliki empati dan tanggung jawab dalam mengelola lingkungan sekolahnya dan bahkan sampai dirumahnya masing-masing.
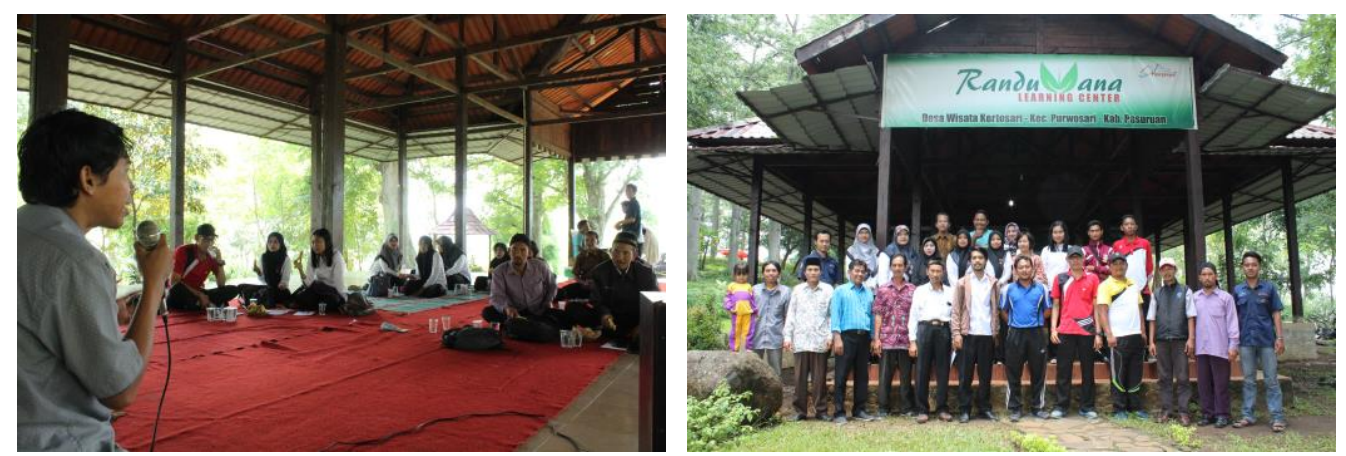

Gambar No.5 Pelatihan Bank Sampah Sekolah 
188 | Pendampingan Gerakan Pendidikan Lingkungan di 12 Lembaga Pendidikan..

\section{Diskusi}

\subsection{Mendefinisakan sampah dan kesadaran pengelolaan sampah}

Persolan pengelolaan lingkungan yang berhubungan dengan sampah sudah dijelaskan dalam Undang-undang (UU) RI Nomor 18 Tahun 2008 tentang Pengelolaan Sampah, dimana didefinisikan bahwa sampah sebagai sisa kegiatan sehari-hari manusia dan/atau proses alam yang berbentuk padat. Sedangkan yang dimaksud dengan sampah rumah tangga adalah sampah yang berasal dari kegiatan sehari-hari dalam rumah tangga, tidak termasuk tinja dan sampah spesifik.(Undang-undang (UU) tentang Pengelolaan Sampah, 2008) Dalam keterangan lain dari hasil penelitian Paulus Hariyono,dkk., tentang kesadaran masyarakat dalam melakukan pemilahan sampah menunjukkan bahwa sebenarnya masyarakat sudah memiliki pengetahuan yang cukup tentang pemilahan sampah, hanya saja masyarakat masih memiliki kemauan dan tindakan yang rendah. Artinya bahwa masih terjadi inkonsistensi antara kognitif (pengetahuan), Afektif (kemauan) dan Psikomotorik (tindakan) pada masyarakat tentang kesadaran pemilahan sampah.

Lebih lanjut dijelaskan dalam hasil kajian tersebut menunjukkan tentang apa alasan yang mendasarai inkonsistensi antara kognitif, afektif dan psikomotorik di atas, yakni: 1) motivasi dalam melakukan realisasi pengetahuan yang dimiliki; 2) keterampilan yang kurang dalam pemilahan sampah maupun dalam mendayagunakan sampah menjadi sesuatu yang memberikan nilai tambah; 3) sampah masih dipandang sebagai sesuatu yang remeh dan menjijikkan; 4) pemilahan sampah masih dipandang sebagai sesuatu yang merepotkan. Yang menarik, kajian tersebut juga mengungkapkan bahwa laki-laki lebih rendah kesadaran dalam memilah sampah daripada wanita, karena wanita bergelut langsung dengan sampah.(Paulus Hariono, 2013) Inkonsistensi pengetahuan, sikap dan perilaku dalam pengelolaan sampah ini menjadi temuan yang cukup penting sebagai landasan dalam program-program pendampingan masyarakat dibidang pengelolaan sampah. Intervensi program setidaknya juga tidak boleh menafikan 
tentang penekakan perubahan perilaku (behavioral change) dengan penguatan karakter (character building) kepedulain terhadap lingkungan yang sebisa mungkin untuk ditanamkan sejak usia dini di masyarakat. Melalui upaya itu setidaknya kesadaran akan pentingnya penanganan sampah bisa dimulai dari masing-masing individu, rumahtangga dan masyarakat.

\subsection{Pentingnya Pendidikan Lingkungan Hidup Bagi Anak Sejak Dini}

Pendidikan lingkungan sebenarnya adalah suatu usaha penanaman sikap dan karakter untuk menjaga dan melestarikan lingkungan agar senantiasa cinta lingkungan. Pendidikan lingkungan hidup memang sangat diperlukan agar setiap orang senantiasa sadar diri dan membiasakan diri untuk menjaga dan melestarikan lingkungan disekitanya. Penanaman karakter cinta lingkungan memang seharusnya dimulai sejak dini dimana masa usia tersebut masuk dalam masa emas (golden age) pembentukan karakter dan sikap pada anak dimana pada usia ini merupakan usia pengenalan diri, karakter serta lingkungan agar anak mengenali lingkungan sekitarnya. Pada usia inilah sangat penting diajarkan hal-hal positif seperti pendidikan lingkungan hidup agar anak tersebut dapat terbiasa sejak dini untuk menerapkan sikap-sikap cinta lingkungan saat ia dewasa nanti.(Retnowati, 2019) Dalam pendidikan lingkungan hidup harus berdasarkan pengalaman langsung bersentuhan dengan lingkungan hidup dengan melibatkan unsur otak (pengetahuan empiris), hati (afektif) serta tangan (Psikomotori) sehingga diharapkan dari pengalaman langsung tersebut dapat membentuk perilaku, nilai dan kebiasaan untuk menghargai lingkungan.(Surakusumah, 2009)

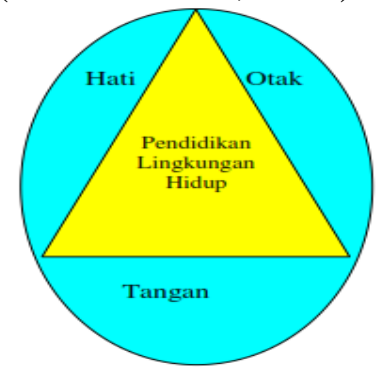

Sumber: Wahyu Surakusumah UPI 
190 | Pendampingan Gerakan Pendidikan Lingkungan di 12 Lembaga Pendidikan..

Upaya untuk menanamkan karakter cinta lingkungan hidup sebenarnya sudah digagas oleh pemerintah dalam hal ini adalah Kementrian Lingkungan Hidup melalui Program pendidikan Sekolah Adiwiyata yang dikembangkan mulai tahun 2016. Program ini bertujuan untuk mendorong warga sekolah agar melek dan memiliki berkarakter peduli lingkungan dengan melakukan pelestarian lingkungan hidup baik didalam sekolah maupun diluar sekolah. Untuk menuju sekolah adiwiyata maka ada standar yang harus dipenuhi oleh sekolah yang mengacu pada Peraturan Menteri Lingkungan Hidup nomor 5 tahun 2013. Pertama, kurikulum dan Rencana Kegiatan dan Anggaran Sekolah (RKAS) berupaya melindungi dan mengelola lingkungan hidup. Kedua, guru kompeten dalam mengembangkan kegiatan pembelajaran berbasis lingkungan sesuai dengan kurikulum. Ketiga, kegiatan lingkungan berbasis partisipatif yang terencana bagi warga sekolah dan mendapat dukungan dari pihak luar. Keempat, kualitas sarana prasarana sekolah dikelola dengan baik mengarah pada ramah lingkungan.(Rezkita \& Wardani, 2018)

Terkait dengan pendidikan usia dini di Kabupaten Pasuruan, pemerintah daerah dalam hal ini Dinas Pendidikan Kabupaten Pasuruan telah mendukung dengan berbagai regulasi maupun support teknis dalam berbagai pelatihan. Data Laporan Kinerja Instansi Pemerintah (LKjIP) Dinas Pendidikan Kabupaten Pasuruan pada tahun 2016 menunjukkan bahwa angka partisipasi kasar masih 82,79\%.11 artinya masih banyak daerah-daerah yang belum mengembangkan pendidikan dasar untuk mendukung optimalisasi potensi masamasa emas anak.(Fathurrohman, Dayat, Apriwiyanto, \& Wibisono, 2018) Untuk mendukung upaya pemerintah daerah tersebut, penanaman character building cinta lingkungan yang dilakukan dalam program ini cukup dirasa berhasil dimana 12 lembaga pendidikan yang terlibat program saat ini telah mampu membangun kesadaran siswa baik secara individu maupaun kelompok dalam penanganan sampah, misalnya disaat jam instirahat siswa sudah mulai terbiasa untuk membuang sampah plastik kemasan sneck yang mereka beli dikantin pada tempat pemilahan sampah yang sudah dibuat oleh sekolah. Dalam hal menanamkan 
karakter peduli lingkungan, dari hasil observasi lapangan yang dilakukan oleh tim Randuwana Learning Center menunjukkan bahwa sekolah mitra program memiliki strategi yang berbeda-beda dalam mengembangkan dan menanamkan karakter peduli lingkungan pada siswa masing-masing. Bebrapa sekolah yang memiliki keterbatasan sarana dan prasarana lebih menguatkan fungsi keorganisasian bank sampah sekolah sebagai upaya mendidik karakter tanggung jawab terhadap lingkungan. Ada penjadwalan pengumpulan sampah, pengemasan dan sampai penjualan sampah ekonomis. Selain itu, keterbatasan dalam hal sarana dan prasarana ataupun kurikulum yang belum terintegrasi tidak menjadikan program ini tidak bisa berjalan. Beberapa sekolah lebih menekankan pada aspek praktek, pengawasan serta pengarahan kepada siswa didik dalam menjalankan program peduli lingkungan

\subsection{Pentingnya Sinergi pendidikan lingkungan berkelanjutan}

Upaya membangun karakter siswa peduli dan cinta terhadap lingkungan memang tidak bisa dilakukan secara parsial. Artinya hanya dilakukan dalam jenjang pendidikan tertentu saja melainkan harus tersinergi secera terus menerus ke level selanjutnya secara konsisnten dan sustainable sehingga karakter tersebut mengakar dengan baik menjadi sebuah kepribadian. Berbagai kasus dilapangan dijumpai pahwa banyak siswa yang mengalami diskontinyu dalam pendidikan lingkungan ketika melanjutkan studi ke jenjang selanjutnya mengingat belum tersinergi dan tersistem dengan baik pendidikan lingkungan tersebut. Karakter yang dibangun sejak dini bisajadi akan hilang ketika siswa terkontaminasi oleh suatu keadaan yang tidak sejalan dengan penanaman karakter di sekolah awalnya baik itu dari internal sekolah ataupun eksternal. Hal tersebut sangat bisa dipahami mengingat jumlah lembaga pendidikan yang menerapkan konsep adiwiyata jumlahnya sangat minim sehingga pendidikan lingkungan menjadi stagnan dan kurang mendapatkan hasil yang menggembirakan. Maka dari itu, perlua danya dukungan dari pemerintah dan semua pihak terkait untuk membuat desain 
192 | Pendampingan Gerakan Pendidikan Lingkungan di 12 Lembaga Pendidikan..

pendidikan yang mengarah pada penguatan environtment maestriming disekolah menuju orientasi pembangunan pendidikan yang berkelanjutan (educatioan for sustainable development). Melalui desain kebijakan berwawasan lingkungan, pelaksanaan kurikulum berbasis lingkungan, kegiatan lingkungan berbasis partisipatif, pengelolaan sarana pendukung ramah lingkungan serta disinergikan dengan pendidikan agama maka akan menghasilkan insan madani yang mempunyai jiwa rohmatan lil alamien yang mampu memerankan peran hablun minal alam seca

Gambar No.6 Model Pendidikan Lingkungan Untuk Pembangunan Berkelanjutan

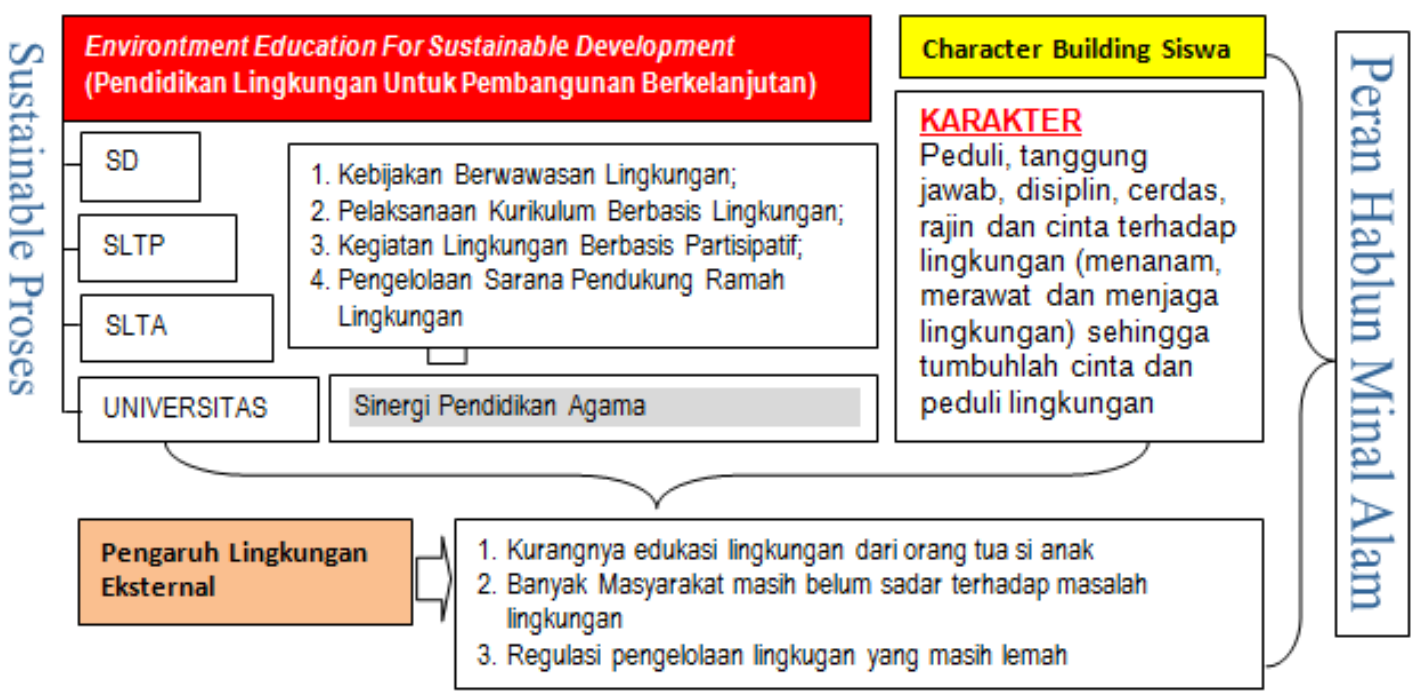

Sumber: Olahan penulis (Zainul Ahwan) 2019

Sejalan dengan pemikiran diatas, Kementrian Pendidikan Nasional Indonesia merespon positif wacana Dekade Pendidikan untuk Pembangunan Berkelanjutan (Decade of Education for Sustainable Development/DESD) dengan menempatkan pendidikan untuk pembangunan berkelanjutan (Education for Ssustainable Development) sebagai salah satu paradigma pendidikan di Indonesia, yaitu : pendidikan menghasilkan manusia berakhlak mulia yang menjadi rahmat bagi semesta alam. Manusia seperti itu memenuhi kebutuhannya dengan memperhatikan kebutuhan generasi saat ini dan generasi-generasi yang akan datang (keberlanjutan intergenerasional)(Priyanto, Djati, Soemarno, \& Fanani, 2013) 


\section{Kesimpulan}

Program Pendampingan Gerakan Pendidikan Lingkungan di 12 Lembaga Pendidikan Dasar (SD \& MI) di Desa Capang, Desa Kertosari dan Desa Tejowangi Kabupaten Pasuruan ini telah dilaksanakan selama 5 bulan Mulai Bulan Januari Mei 2018. Dalam pelaksanaan program 12 lembaga pendidikan dasar yang menjadi mitra telah bekerjasama dan mengikuti kegiatan dengan aktif mulai dari asesmen, workshop inisiasi program, Pembuatan dan pengelolaan serta pemanfaatan taman TOGA di sekolah, pelatihan bank sampah sekolah. Dari program ini telah menghasilkan komunitas rintisan pendidikan adiwiyata di 3 desa yaitu desa Kertosari, Capang dan Tejowangi. Program ini telah memberikan pengetahuan dan skill pada guru dan siswa di 12 lembaga pendidikan dasar tentang petingnya karakter kepedulain lingkungan hidup pada siswa, selain itu, mitra program juga memiliki pengetahuan dan skill dalam pengelolaan lingkungan dikawasan sekolah melaui benk sampah sekolah dan penanaman dan pemanfaatan tanaman TOGA di masing-masing sekolah. Selain itu, untuk mendorong keberlanjutan program dukungan dari berbagai pihak terkait sangat dibutuhkan mengingat inisiasi sekolah adiwiyata di 12 lembaga pendidikan dasar tersebut masih membutuhkan pengembangan sarana dan prasarana serta pendalaman dan penguatan kurikulum yang masih belum tersinergi secara penuh dengan program yang dikembangkan. Dalam konteks makro, program pendampingan gerakan pendidikan lingkungan tidak bisa sukses hanya berjalan di instansi pendidikan pada level tertentu saja, namun harus sejalan secara ninergis dan sustainable disemua level pendidikan untuk mendapatkan hasil yang nyata dan terukur dalam menanamkan karakter cinta dan peduli lingkungan. 
194 | Pendampingan Gerakan Pendidikan Lingkungan di 12 Lembaga Pendidikan..

\section{Ucapan Terima Kasih}

Ucapan terima kasih disampaikan kepada kepala Lembaga Pendidikan Dasar (SD \& MI) di Desa Capang, Desa Kertosari dan Desa Tejowangi Kabupaten Pasuruan sehingga program pendampingan gerakan pendidikan lingkungan ini dapat terlaksana dengan baik.

\section{Daftar Pustaka}

Ahwan, Z., Hasyim, M., \& Sunarno, H. (2019). Pendampingan Pemuda Suku Tengger dalam Pengembangan Wisata Kawasan Hinterland Gunung Bromo Sebagai Wisata Alam Dan Budaya Suku Tengger di Kabupaten Pasuruan. Engagement: Jurnal Pengabdian Kepada Masyarakat, 3(2), 173-192. Arifin, M. (2016). Ini Penyebab Pasuruan Jadi Langganan Banjir. Retrieved May 28, 2020, from www.news.detik.com website: https://news.detik.com/beritajawa-timur/d-3343810/ini-penyebab-pasuruan-jadi-langganan-banjir

Fathurrohman, A., Dayat, M., Apriwiyanto, S., \& Wibisono, M. (2018). Shodaqoh

Sampah Usia Dini : Implementasi Program Shodaqoh Sampah pada

Pendidikan Usia Dini Wanjati Junior Pandaan Pasuruan. Annual Conference for Muslim Scholars, 1(2), 711-720. Retrieved from

Imron Rosadi, Faris, Zainul Ahwan, M. W. (2019). Modernisasi Manajemen Bank

Sampah Melalui Pemanfaatan Aplikasi Bank Sampah IT Mobile Pada

Komunitas Bank Sampah TPI BISA Kelurahan Pagak Kecamatan Beji Kab.

Pasuruan. 2(November), 1-18.

Paulus Hariono, D. (2013). Kesadaran Pemilahan Sampah Rumah Tangga pada

Masyarakat Kota Semarang dan Yogyakarta. Seri Kajian Ilmiah, 15(1).

Priyanto, Y., Djati, M. . S., Soemarno, \& Fanani, Z. (2013). Pendidikan

Berperspektif Lingkungan Menuju Pembangunan Berkelanjutan. Wacana, 16(1), 41-51.

Retnowati, P. (2019). Pentingnya Pendidikan Lingkungan Hidup Bagi Anak Sejak Dini. Retrieved May 28, 2020, from 
http://blog.unnes.ac.id/pancarretnowati/2015/11/19/pentingnya-pendidikanlingkungan-hidup-bagi-anak-sejak-dini/

Rezkita, S., \& Wardani, K. (2018). Karakter Peduli Lingkungan di Sekolah Dasar. TRIHAYU: Jurnal Pendidikan Ke-SD-an 4.2, 327-331.

RPJMD Kabupaten Pasuruan Tahun 2018-2023. (2019).

Surakusumah, W. (2009). Konsep pendidikan lingkungan di sekolah: model uji coba sekolah berwawasan lingkungan. Bandung: Universitas Pendidikan Indonesia. Retrieved from

WAHYU_SURAKUSUMAH/Konsep_Pendidikan_Lingkungan_Hidup.pdf Undang-undang (UU) tentang Pengelolaan Sampah. , (2008). 
196 | Pendampingan Gerakan Pendidikan Lingkungan di 12 Lembaga Pendidikan.. 